\title{
DYSTOPIAN FICTION IN ENGLISH: A CORPUS-DRIVEN ANALYSIS OF ESTEEM IN VERONICA ROTH'S "DIVERGENT" TRILOGY
}

\author{
Andrea Burgos Mascarell \\ Universidad de Valencia \\ andrea.burgos@uv.es
}

\begin{abstract}
In light of the recent wave of popularity of dystopian fiction for young adults, and in particular of Veronica Roth's trilogy Divergent, research has begun to focus on this subgenre. However, the focus tends to be on educational and gender approaches to the novels, while the psychological aspects of the characters have been largely ignored. My study focuses on the representation of esteem and self-esteem in the trilogy through an analysis based on annotation. The results shed light on the factors that affect the protagonist's role and selfrepresentation.
\end{abstract}

KEYWORDS: Dystopia, young adult, Divergent, self-esteem, esteem, annotation.

\section{LA FICCIÓN DISTÓPICA EN INGLÉS: ANÁLISIS DE LA ESTIMA GUIADO POR EL CORPUS DE LA TRILOGÍA "DIVERGENTE", DE VERONICA ROTH}

\footnotetext{
RESUMEN: Dada la reciente popularidad de la ficción distópica juvenil y en particular de la trilogía Divergente, de Veronica Roth, se ha empezado a investigar este subgénero. Sin embargo, actualmente la investigación se tiende a centrar en enfoques de género y educativos, ignorando en general los aspectos psicológicos de los personajes. Mi estudio se centra en la representación de la estima y autoestima a través de un análisis basado en la anotación. Los resultados ofrecen información sobre los factores que afectan el rol y autoestima de la protagonista.

PALABRAS CLAVE: distopia, joven-adulto, Divergente, autoestima, estima, anotación.
} 


\title{
LA FICTION DYSTOPIQUE EN ANGLAIS: ANALYSE DE L'ESTIME GUIDÉE POUR LE CORPUS DE LA TRILOGIE «DIVERGENTE», DE VERONICA ROTH
}

\begin{abstract}
RÉSUMÉ : Compte tenu de la popularité récente de la fiction dystopique pour adolescents et en particulier de la trilogie Divergente, de Veronica Roth, les chercheurs ont commencé à s'intéresser sur ce sous-genre. Actuellement la recherche tend à se concentrer sur les approches de genre et éducatives sans prendre en compter en général les aspects psychologiques des personnages. Mon article se concentre en la représentation de l'estime et de l'estime de soi à travers d'une analyse basée sur l'annotation. Les résultats offrent des informations sur les facteurs qui affectent le rôle et l'estime de soi de la protagoniste.

MOTS CLÉ : dystopie, adolescents, Divergente, estime de soi, estime, annotation.
\end{abstract}

Recibido: 06/01/2020. Aceptado: 12/11/2020

\section{Introduction}

The increase in popularity of dystopian fiction novels over the last decade seems unquestionable. Dystopian fiction, the literary subgenre that focuses on the representation of gloomy futures based on current problems, regained its former strength with a new target audience: young adults. The success of this subgenre found its peak in the publication and adaptation of The Hunger Games trilogy, by Suzanne Collins $(2008,2009,2010)$. This trilogy paved the way for similar novels that reached comparable reception, the most successful pupil being the Divergent trilogy, by Veronica Roth $(2011,2012,2013)$.

The subgenre's high popularity brought an increase in scholarly interest. Indeed, research on YA dystopian novels is significant, with a great portion of it focusing on the educational applications of these novels to the classroom. Another key research area is directly connected to the fact that the protagonists of this new wave of dystopian fiction are mostly female. This fact has also led to a variety of perspectives regarding the protagonists' affiliation decisions, including romantic interests and whether their attitudes towards these relationships are subversive enough of current gender roles and stereotypes. Nevertheless, and despite the weight of dramatic and traumatic events in these novels, little research 
has focused on the protagonists' esteem and self-esteem from the point of view of literature and linguistics.

This study offers an original contribution to the literature on the esteem of protagonists of dystopian novels for young adults through a corpus-driven analysis of esteem in Veronica Roth's acclaimed trilogy Divergent. The analysis uses annotation and is followed by a discussion of the results that shows the protagonists' psychological trends in this regard and others' opinions about the protagonist. This information suggests not only the social status of the protagonist but also whether and to what extent the positive and negative opinions of others affect the protagonist's self-esteem.

The study is structured as follows: Section 2 includes a review of the literature on dystopian fiction and esteem as well as the method chosen. Section 3 presents the results of the analysis, organized in tables that include the extracts with the tags that identify a piece of text as a positive or negative opinion of the self or by others. Section 4 presents a discussion and the conclusion, including some ideas for future research.

\section{Review of the literature}

Utopian literature has a long tradition in the English-speaking world, not in vain was an English work the one that gave the genre its name: Saint Thomas More's Utopia or De Optimo Rei Publicae Statu, Deque Nova Insula Utopia (1516). Nevertheless, the utopian impulse has representations in the Greek and Roman traditions and in other countries, such as Italy (e.g., Tomaso Campanella's City of the Sun, 1602). The anti-utopian tradition, which has its most notable representation in the $18^{\text {th }}$ century satire Gulliver's Travels (Swift 1723), gave voice to those who questioned the inherent positivism in utopian literature. Nevertheless, the $20^{\text {th }}$ century, with its two world wars and dictatorial regimes, gave rise to the development of the negative alternative, the subgenre that represented pessimistic and comparatively worse societies: dystopian literature.

The prevalence of one or another subgenre varies in light of the political and socioeconomic context. Thus, with the negative prospects that economic crises bring, the 2008-2016 period was particularly apt for dystopian fiction to thrive. However, unlike previous waves of popularity, this period presented an increase in youngsters' interest in this subgenre. These novels often deal with intrinsically corrupt systems that affect the young protagonists' possibilities to thrive, which is highly related to the prevalence of the bildungsroman in YA fiction. Indeed, given 
that the new wave of YA dystopian fiction is very recent, and that the previous period of this phenomenon took place in the early 1990s, few scholars have delved into the traits of this subgenre, but those who have seem to agree on the influence of the Bildungsroman (Pataki 2017: 429). This connection is evidenced by the commonly used trope of lies and secrets of authorities in the society that are -sometimes gradually- discovered by the protagonist in a way that evokes the children who come of age and learn about the dissatisfactory features of the adult world that they had been spared during childhood (Hintz and Ostry 2003: 9). Furthermore, adolescents are often given the Romantic task of saving adults (p. 10). However, the main focus of YA literature seems to be on interrogating "social constructions, foregrounding the relationship between society and the individual rather than focusing on Self and self-discovery" (Trites 2000: 20). Thus, YA dystopian fiction seems to have drawn on this already established trend to become successful.

The basis of utopian and dystopian fiction, the alternative society, has promoted analyses of those societies on many levels: education, interpersonal relationships, power relationships, economic systems, etc. Research focusing on the YA version of dystopian fiction has tended to focus on psychological and sociological aspects of the protagonists through different approaches such as ecocriticism, gender, cultural studies, etc. On the other hand, the application of YA dystopian fiction to the classroom has also been widely researched.

In this regard, over the last decade, scholars have stressed the suitability of using dystopian fiction in the classroom to foster students' engagement with the texts and with the social issues narrated. In particular, Ames (2013: 4) suggests that using these texts could be useful to spark political action among young adults. Similarly, Marshall (2014: 141) suggests that YA dystopian texts can be used in class to foster English and Arts students' critical and analytical literacy skills. Simmons (2014: 77) applied The Hunger Games to the classroom by encouraging students to make connections between the violence of the novels and the reality of their society and to actively participate in actions that could minimise that violence. Saunders (2014: 44) discusses the wide array of possibilities offered by Suzanne Collins' texts in the classroom through an interdisciplinary perspective, including literacy-based lessons focusing on English, maths, history and science. Piotrowski and Rybakova (2015: 23-26) include The Hunger Games and Divergent trilogies among their choice of texts to help students develop a healthy concept of gender by analysing these novels through the lens of feminism. 
In a reader-response approach to The Hunger Games' first novel, Jerković and Alihodžić (2018: 233) discuss adolescents' perception of the connections between the novel's dystopian setting and the overall negative environment in post-war Bosnia Herzegovina, concluding that this socioeconomic environment draws adolescents to this type of literature. Soares (2018), as Ames (2013) did, urges teachers to incorporate dystopian fiction as a pedagogical tool to address current issues. At university level, Ames (2018: 23) discusses the advantages and challenges of applying dystopian fiction -including fiction for young adultsto a cross-curricular composition module focusing on ethical issues related to progress.

Research on the pedagogical use of YA dystopian fiction is being undertaken also by postgraduate students and $\mathrm{PhD}$ candidates. Breen (2015: 55) conducted a reader-response approach to the influence of recreational reading of the dystopian novel The Giver (Lowry 1993/2014), on undergraduate's development of critical thinking, social and rationalization skills but also language proficiency. Ball analysed students' perceptions of protagonists of YA dystopian novels including Divergent. By doing so, she explored the degree of identification of the readers with the protagonists but also found that female readers tend to be more critical of the author's characterisation of the protagonists, considering the latter victims of their agendas (Ball 2016: 95). Recently, Van Melckebeke (2018: 9) analysed Scott Westerfeld's Uglies trilogy (2005-2006) to identify topics that can be used in teaching English in the classroom.

Many of the contributions addressing YA dystopian fiction are collections of essays, each dealing with one or two novels and a specific topic. Although written before the first of the novels of the corpus was published, Hitz and Ostry's (2003) book Utopian and Dystopian Writing for Children and Young Adults comprises a collection of essays on transport, politics, children's agency and utopias and dystopias after World War II. Indeed, education is only one of the areas of study where YA dystopian fiction has been applied. Rather significantly, given that many of the most popular YA dystopias have a female protagonist, gender is a key approach. Especially interesting is the focus on The Hunger Games and the protagonist, Katniss. While her behaviour has been examined and interpreted as challenging traditional gender roles, other studies criticise the fact that social criticism fails to cover romance. Probably one of the most insightful works on gender and YA dystopian fiction is Female Rebellion in Young Adult Dystopian Fiction (Day et al. 2014). This collection of essays deals with several YA dystopian novels, including Divergent, and examines topics such as agency, 
sexual awakening and female friendship. Another comprehensive account of YA dystopian fiction is the essay collection Contemporary Dystopian Fiction for Young Adults: Brave New Teenagers (Basu, Broad and Hinz 2014), which explores topics of this subgenre in a wide array of texts including adolescent liberty in Divergent. Because of the type of audience to which these novels are addressed, protagonists may be conceived as role models and their behaviour and values may be imitated by the readership. Furthermore, dystopian fictional societies depict alternative worlds based on the extrapolation of negative traits of our present societies. Therefore, the way the system affects a character is an important part of the text and intended to be considered by the reader as a potential threat unless it is prevented. In particular, strict or authoritarian systems and the psychological and/or physical abuse of the protagonists can be seen in classic dystopias such as 1984 or Brave New World, the latter depicting a system where a misfit is unable to thrive due to the strict classification of humankind. Therefore, and taking into account the psychological consequences that dystopian traumatic events may have on the characters, it is paramount to identify patterns in esteem, not only as the stage of status acquisition and respect, but also as referred to the characters' perception of themselves.

In order to identify self-esteem and esteem patterns, I have used a corpus linguistics technique: Annotation. Using annotation involves tagging the text so that the excerpts can be extracted and identified more easily. In this sense, I have chosen four tags: [PSR], [NSR], [PRBO], [NRBO], which stand for positive self-representation, negative self-representation, positive representation by others and negative representation by others. Thus, I proceeded to manually add the corresponding tag next to each instance of text where the protagonist refers to herself or is referred to by others in positive or negative terms. The results of this annotation process are presented in tables, and each of the quotes is followed by the tag and the page number of the novel analysed.

Regarding previous applications of corpus linguistics to creative texts, Hoover, Culpeper and O'Halloran (2014) applied it to prose, poetry and drama in the field of Digital Humanities defending the complementary nature of corpus linguistics with regards to traditional approaches. On the other hand, Koutsoulelou (2017) applied corpus linguistics to a set of Greek songs to analyse the cultural impact of the global economic crisis on the country. These approaches, however, take relatively non-extensive pieces of text that are self-contained, while my approach takes a trilogy of YA dystopian novels each of which is between 487 and 526 pages long. 


\section{Results}

\subsection{Results: Divergent}

The following table presents the results for Divergent including positive and negative self-representation and positive and negative descriptions of the protagonist by others.

Table 1. Results of annotation applied to the representation of esteem and self-esteem in Divergent

\begin{tabular}{|l|l|}
\hline 1 & $\begin{array}{l}\text { I grab Caleb's arm as I stumble over the man's shoes. My slacks are too long, } \\
\text { and I've never been that graceful. [NSR] (p. 4) }\end{array}$ \\
\hline 2 & $\begin{array}{l}\text { 'Just do what you're supposed to,' he always says. It is that easy for him. It } \\
\text { should be that easy for me. [NSR] (p. 10) }\end{array}$ \\
\hline 3 & I watch myself, pale and terrified, walking toward one of the doors. [NSR] (p. 11) \\
\hline 4 & $\begin{array}{l}\text { I sit forward and wipe my palms off on my slacks. I had to have done } \\
\text { something wrong, even if it only happened in my mind. [NSR] (p. 19) }\end{array}$ \\
\hline 5 & $\begin{array}{l}\text { Is that strange look on Tori's face because she doesn't know how to tell me what } \\
\text { a terrible person I am? I wish she would just come out with it. [NSR] (p. 19) }\end{array}$ \\
\hline 6 & $\begin{array}{l}\text { My voice sounds clear and stern-not what I expected to hear. I feel like it } \\
\text { doesn't belong to me. [NSR] (p. 26) }\end{array}$ \\
\hline 7 & $\begin{array}{l}\text { Why was I so focused on myself that I didn't notice his deep frown and his } \\
\text { sagging posture? [NSR] (p. 33) }\end{array}$ \\
\hline 8 & $\begin{array}{l}\text { I stare at my peas. I am not sure I can live this life of obligation any longer. I } \\
\text { am not good enough. [NSR] (p. 35) }\end{array}$ \\
\hline 9 & $\begin{array}{l}\text { But I am not selfless enough. Sixteen years of trying and I am not enough. } \\
\text { [NSR] (p. 43) }\end{array}$ \\
\hline 10 & $\begin{array}{l}\text { Then, with a gasp I can't contain, I shift my hand forward, and my blood } \\
\text { sizzles on the coals. I am selfish. I am brave. [NSR] [PSR] (p. 47) }\end{array}$ \\
\hline 11 & $\begin{array}{l}\text { Clumsily, [NSR] I fumble along the side of my head to find the edge of the } \\
\text { blindfold. (p. 280) }\end{array}$ \\
\hline 12 & $\begin{array}{l}\text { Choosing to quit, to be factionless, would be the bravest thing I have ever } \\
\text { done, and today I feel like a coward. [NSR] (p. 347) }\end{array}$ \\
\hline 13 & $\begin{array}{l}\text { My worst fear: that my family will die, and that I will be responsible. [NSR] } \\
\text { (p. 395) }\end{array}$ \\
\hline 14 & I am weak from blood loss and too small. [NSR] (p. 433) \\
\hline 17 & $\begin{array}{l}\text { I feel like someone breathed new air into my lungs. I am not Abnegation. I am } \\
\text { not Dauntless. I am Divergent. And I can't be controlled. [PSR] (p. 442) }\end{array}$ \\
\hline Somehow, I get up and start running. I am brave. [PSR] (p. 444)
\end{tabular}


Tris' account of herself is extensive. Examples 1 to 14 depict Tris' negative representations of herself. Multiple groups can be distinguished. On the one hand, examples 3, 6 and 14 refer to her body. In the first case (3) she describes the way she looks. In the second case, she indicates that her perception of herself is lower than reality because she is surprised when her voice sounds "clear and stern." Finally, in example 14, she conveys a negative image of her body, described as too small to be able to fight and win. The adverb "too" is key in this case.

On the other hand, examples 2, 4, 5, 8 and 9 indicate a low self-esteem as regards her abilities and personality. All these examples reflect her inability to comply with the Abnegation lifestyle and the fact that she has been chastised on several occasions for not behaving as selflessly as all members of that community should. It is noteworthy that all these examples take place during the first part of the novel, before she leaves Abnegation for Dauntless. This idea is relevant because it could indicate that the system was too strict and affected children psychologically in the cases where their aptitudes did not match the faction in which they were raised. Furthermore, the lack of family support to reach these standards and to express herself cause her to lose confidence.

The remaining examples indicate a negative self-image related to her skills (examples 1 and 11 depict her as clumsy) and her behaviour. Example 12 uses the word "coward," which is recurrent throughout the novels, because in Dauntless people's worth is measured in terms of bravery. However, this conception of herself is far from being the norm. On the other hand, example 13 shows the idea that she feels guilty for the pain and harm that could come to her family due to her actions. In this case, she follows a common pattern among heroes, where the protagonists feel the weight of social pressure to perform as expected and not to cause harm with one's decisions. This idea is based on the fact that prioritising her needs to those of others goes against her culture, Abnegation, which is feminine and collectivist. However, it is also linked to her struggle to gain agency. If there is a word that can describe Tris is conflicted, as represented by example 15 . Her identity is divided and so is her personality and the actions shaped by both her upbringing and her training.

Regarding positive representations, examples 15 and 16 show that she takes pride in being brave, the only positive word she uses to describe herself in this first novel and the word that defines her actions throughout the trilogy. Only one example shows a positive description of Tris by a third person. In fact, it is her idea of what Four thinks of her (example 16) and it has to do with strength and resilience. The lack of social support is patent here. She does not receive support or positive reinforcement from her family or friends in this first instalment. 
Finally, although no results are disclosed as regards negative representation by others, there is a constant teasing and attacking attitude on the part of a small group of initiates, led by Peter. They address her with the word "stiff," which is slang for Abnegation, but it is not always used in a negative sense and therefore cannot be objectively pointed out. A qualitative examination, however, shows that Peter and the others display a bullying and deprecating behaviour towards Tris as shown, for instance, by the painting of the word "stiff" across her mattress, or the violent attack she endures. However, this situation is arguably more related to safety than to esteem.

\subsection{Results: Insurgent}

The analysis of self-esteem and esteem for the Divergent series continues in the following table, which includes the examples for the second novel.

Table 2. Results of annotation applied to the representation of esteem and self-esteem in Insurgent

\begin{tabular}{|l|l|}
\hline 1 & I feel suffocated, but at least I feel strong. [NSR] (p. 23) \\
\hline 2 & $\begin{array}{l}\text { "You may have succeeded in shutting down the attack simulation, girl, but } \\
\text { it was by luck alone, not skill. I would die of shock if you managed to do } \\
\text { anything useful again for a long time." [NRBO] (p. 45) }\end{array}$ \\
\hline 3 & $\begin{array}{l}\text { I know that I am birdlike, made narrow and small as if for taking flight, built } \\
\text { straight-waisted and fragile. [NSR] (p. 49) }\end{array}$ \\
\hline 4 & $\begin{array}{l}\text { He smirks. "If only you could see how ridiculous you look when you threaten } \\
\text { people. Like a little girl telling me she's going to strangle me. [NRBO] (p. 55) }\end{array}$ \\
\hline 5 & $\begin{array}{l}\text { He's handsome, isn't he? I don't really know why he likes me so much. I'm } \\
\text { not very nice, am I? [NSR] (p. 60) }\end{array}$ \\
\hline 6 & $\begin{array}{l}\text { The Abnegation are dying again, dying like they were when I pretended to be } \\
\text { under the simulation. And all I'm doing is running. [NSR] (p. 84) }\end{array}$ \\
\hline 7 & $\begin{array}{l}\text { He still believes that I am strong. Strong enough that I don't need his } \\
\text { sympathy. [PRBO] (p. 85) }\end{array}$ \\
\hline 8 & $\begin{array}{l}\text { It is my fault, of course, that that was never a possibility, because I chose } \\
\text { another faction. [NSR] (p. 114) }\end{array}$ \\
\hline 9 & $\begin{array}{l}\text { I am the only thing that kept him in the faction he wanted to leave. I am not } \\
\text { worth that. [NSR] (p. 144) }\end{array}$ \\
\hline 10 & $\begin{array}{l}\text { I am tired of being Tris. I have done bad things. I can't take them back, and } \\
\text { they are part of who I am. [NSR] (p. 157) }\end{array}$ \\
\hline 11 & $\begin{array}{l}\text { "You're ridiculous, is what you are." She sighs. "Get your stuff together. } \\
\text { You're Dauntless, and it's time you acted like it. [NRBO] (p. 163) }\end{array}$ \\
\hline
\end{tabular}




\begin{tabular}{|c|c|}
\hline 12 & $\begin{array}{l}\text { "You are brave," she says. "You don't need me to say it, because you already } \\
\text { know it. [PRBO] (p. 170) }\end{array}$ \\
\hline 13 & $\begin{array}{l}\text { "I meant don't let anyone else do anything stupid. They'll listen to you." } \\
\text { [PRBO] (p. 171) }\end{array}$ \\
\hline 14 & $\begin{array}{l}\text { I scream into gritted teeth, frustrated. I can't help. I am worthless. [NSR] (p. } \\
\text { 195) }\end{array}$ \\
\hline 15 & $\begin{array}{l}\text { I glance up at my reflection. My jaw is swollen, and fingernail marks are still } \\
\text { on my arms. Disgusting. [NSR] (p. 200) }\end{array}$ \\
\hline 16 & $\begin{array}{l}\text { "It's not brave, choosing the position you were in yesterday. It's beyond } \\
\text { stupid-it's suicidal. [NRBO] (p. 211) }\end{array}$ \\
\hline 17 & I can't launch an attack based on a little girl's speculations" [NRBO] (p. 222) \\
\hline 18 & $\begin{array}{l}\text { That way, you can look at her without wanting to punch her in her } \\
\text { exceptionally long nose.” [NRBO] My hand moves automatically to my nose. } \\
\text { (p. 223) }\end{array}$ \\
\hline 19 & $\begin{array}{l}\text { "I don't know where you get this delusion that I'm useless, but that's what it } \\
\text { is," I snap. [PSR] (p. 244) }\end{array}$ \\
\hline 20 & $\begin{array}{l}\text { I wonder how I seem to them. They must see someone I don't see. Someone } \\
\text { capable and strong. Someone I can't be; someone I can't be. [NSR] (p. 265) }\end{array}$ \\
\hline 21 & $\begin{array}{l}\text { How is it that only half of us are left? I feel responsible for that. [NSR] (p. } \\
\text { 284) }\end{array}$ \\
\hline 22 & "Because you're better at it than I am." [PRBO] (p. 286) \\
\hline 23 & $\begin{array}{l}\text { I know he's strong, steady, unstoppable. All things I need to be, but I am not, } \\
\text { I am not. [NSR] (p. 312) }\end{array}$ \\
\hline 24 & $\begin{array}{l}\text { Hope and pray and wish that no one else dies because of my selfishness. } \\
\text { [NSR] (p. 319) }\end{array}$ \\
\hline 25 & $\begin{array}{l}\text { Again I feel guilt and grief clawing inside me, warring with each other for } \\
\text { dominance...[NSR] (p. 322) }\end{array}$ \\
\hline 26 & $\begin{array}{l}\text { "You're the bravest person I've ever met. Stay here. Let yourself mend." } \\
\text { [PRBO] (p. 424) }\end{array}$ \\
\hline 27 & $\begin{array}{l}\text { "Why would it?" I say softly, so no one else can hear "After all I've done ..." } \\
\text { [NSR] (p. 440) }\end{array}$ \\
\hline 28 & $\begin{array}{l}\text { "Shooting people who get in your way is a Dauntless trait, after all." I feel a } \\
\text { pinch at the back of my throat. [NRBO] (p. 444) }\end{array}$ \\
\hline
\end{tabular}

As in the previous novel, Tris continues to refer to her body in a negative way. In a general way, she refers to her appearance after the struggle as "disgusting" (15). In example 3, she repeats the fact that she is slim framed, which is reflected as an insecurity especially in her relationship with Tobias (Four). In fact, examples 5 and 9 show that she feels inferior to Tobias in a way. Example 9 indicates 
that she feels guilty for the fact that he stayed in the faction system instead of pursuing what he wanted. Blame is also a constant in these novels.

Examples 8, 21, 24 and 27 depict her guilt and the burden she carries. In example 4, she feels like she prevented her neighbour from having her idealised life in Abnegation, because she decided to pursue her career as a Dauntless, which reflects the social pressure she endures. On a bleaker note, she blames herself for the deaths of others because she is Divergent and is the target of those killing innocent citizens (24). In fact, she considers that she is not worthy of forgiveness (27).

In more general terms, due to inaction or to her choices, examples 6,10 and 25 show Tris' inner conflict. Example 10 is noteworthy for her acceptance of what she has become, her bad decisions included. Nevertheless, the tone indicates symptoms of depression, as she claims that she is tired of being who she is. In this vein, she remembers her late friend, who jumped into the chasm because he was tired of who he was, which indicates that she considers that alternative in relation to her situation at that moment. In fact, her frustration over her inability to solve the conflict or being strong enough is patent in examples 14 , 20, and 23. Examples 20 and 23 are remarkably similar in the choice of structure. She repeats that she cannot be what Tobias is (strong, unstoppable...), what she demands herself to be (23). Similarly, she fails to see the good traits that other people see in her (20).

In contrast to all the negative examples, and perhaps not surprisingly, only in two instances does Tris make positive remarks about herself $(1,19)$. As Tobias mentions somewhere else in the novels, Tris becomes brave and strong when she faces an obstacle. In this case, when she faces Peter, she defines herself in positive terms (19).

Examples 7, 12, 13, 22 and 26 show positive descriptions of Tris by others. It is highly relevant to notice that four out of five are made by Tobias, who is romantically involved with Tris. In example 12, Lynn reassures Tris on her bravery. However, she says so as if she already knew it, and it were annoying for her to have to remind Tris of that. Throughout the novels, Tris appears to be a strong character, with very positive aptitudes, who insists on undervaluing herself.

Regarding negative perceptions or statements about Tris, examples 2 and 4 are made by anti-heroes Marcus and Peter. Examples 11 and 16, by Lynn and Tobias, represent a change: people close to Tris begin to chastise her for being reckless or not valuing herself enough. Tris lies to Tobias on various occasions and puts herself 
in unnecessary danger, thus mining his trust and making him doubt her psychological stability. Example 17 shows how she is not taken seriously because of her age. Nevertheless, the statements that seem to have an impact on Tris are Cara's (18 and 28). The first one refers to her physical appearance, which Tris has shown to be insecure about. The second highlights her mistakes, which include killing a friend in an exceptional situation. All in all, we see a lack of support from friends and a recriminating stance of those friends, which undermines her self-assurance.

\subsection{Results: Allegiant}

Lastly, the table below comprises the results of the analysis of self-esteem and esteem in the last novel, which in this case have Tobias and Tris as co-protagonists.

Table 3. Results of annotation applied to the representation of esteem and self-esteem in Allegiant

\begin{tabular}{|c|c|}
\hline 1 & $\begin{array}{l}\text { Thank you for trying to prevent one of your faction leaders from killing } \\
\text { Jeanine Matthews? You [Tris] behaved like a traitor." Evelyn Johnson spits the } \\
\text { word like a snake. [NRBO] (p. 11) }\end{array}$ \\
\hline 2 & $\begin{array}{l}\text { I don't know when I became so good at acting, but I guess it's not that } \\
\text { different from lying, [NSR] which I have always had a talent for. (p. 12) }\end{array}$ \\
\hline 3 & $\begin{array}{l}\text { He shakes his head. "I just... I'm not used to telling people things. I'm used } \\
\text { to handling things on my own." } \\
\text { "I'm reliable," I say. "You can trust me. And you can let me be the judge of } \\
\text { what I can handle." [PSR] (p. 28) }\end{array}$ \\
\hline 4 & $\begin{array}{l}\text { I do like to hit people-I like the explosion of power and energy, and the } \\
\text { feeling that I am untouchable because I can hurt people. But I hate that part of } \\
\text { myself, because it is the part of me that is the most broken. [NSR] (p. 78) }\end{array}$ \\
\hline 5 & $\begin{array}{l}\text { Rather than angry, I just feel heavy, useless. [NSR] I don't want to think about } \\
\text { him anymore. (p. 85) }\end{array}$ \\
\hline 6 & "A lot of the younger people think you're downright heroic." [PRBO] (p. 148) \\
\hline 7 & $\begin{array}{l}\text { The word "damaged" sinks inside me like it's made of lead. I guess I always } \\
\text { knew there was something wrong with me, [NSR] but I thought it was } \\
\text { because of my father, or my mother [...]. (p. 176) }\end{array}$ \\
\hline 8 & $\begin{array}{l}\text { "Yeah, I do!" Tris exclaims. "You're the same person you were five minutes } \\
\text { ago and four months ago. [PRBO] (p. 177) }\end{array}$ \\
\hline 9 & $\begin{array}{l}\text { I am separate from this place and these people and my own body, and besides, } \\
\text { I have always been a good runner. [PSR] (p. 198) }\end{array}$ \\
\hline 10 & $\begin{array}{l}\text { And even beyond that reasonable suspicion, I have brewing inside me } \\
\text { the desperate hope that I am not damaged, that I am worth more than the } \\
\text { corrected genes I pass on to any children I might have. [NSR] (p. 236) }\end{array}$ \\
\hline
\end{tabular}




\begin{tabular}{|c|c|}
\hline 11 & $\begin{array}{l}\text { I am not a desperate, unsteady child who throws his trust around. I am not } \\
\text { damaged. [PSR] (p. 274) }\end{array}$ \\
\hline 12 & $\begin{array}{l}\text { The Bureau is responsible for my parents' deaths. Why do I have to keep } \\
\text { repeating it to myself to believe it? What's wrong with me? [NSR] (p. 277) }\end{array}$ \\
\hline 13 & $\begin{array}{l}\text { You're all set." I nod. I wish I could tell her that I'm not a hero, [NSR] that I } \\
\text { was using him as a shield, like a wall of meat. (p. 293) }\end{array}$ \\
\hline 14 & $\begin{array}{l}\text { As I look at them, Rafi meets my eyes and nods. As if to say, Well done. If I } \\
\text { did well, why do I feel sick to my stomach? [PRBO] (p. 297) }\end{array}$ \\
\hline 15 & $\begin{array}{l}\text { How many of those am I responsible for, because I participated in this? [NSR] } \\
\text { (p. 298) }\end{array}$ \\
\hline 16 & $\begin{array}{l}\text { Do you understand these terms?" With the words "genetic deficiency" } \\
\text { lingering in my mind, I nod and say, "I do." [NRBO] (p. 303) }\end{array}$ \\
\hline 17 & $\begin{array}{l}\text { I wanted to believe they were all wrong about me, that I was not limited } \\
\text { by my genes, that I was no more damaged than any other person. But } \\
\text { how can that be true, when my actions landed Uriah in the hospital, } \\
\text { when Tris can't even look me in the eye, when so many people died? } \\
\text { [NSR] (p. 304) }\end{array}$ \\
\hline 18 & $\begin{array}{l}\text { "You seem to get involved in a lot of conflict. I suppose we should all be } \\
\text { grateful that you are steady in a crisis." [PRBO] (p. 306) }\end{array}$ \\
\hline 19 & $\begin{array}{l}\text { I feel like what I have become is halfway between my mother and my father, } \\
\text { violent and impulsive and desperate and afraid. I feel like I have lost control } \\
\text { of what I have become. [NSR] (p. 318) }\end{array}$ \\
\hline 20 & $\begin{array}{l}\text { Now I know that I have done something to make myself worthy of that } \\
\text { hatred; I have betrayed them all. [NSR] (p. 335) }\end{array}$ \\
\hline 21 & $\begin{array}{l}\text { I thought of how strong I have become, how secure I feel with the person I } \\
\text { now am, [PRBO] and how all along the way he has told me that I am brave, I } \\
\text { am respected, I am loved and worth loving. (p. 372) }\end{array}$ \\
\hline 22 & $\begin{array}{l}\text { "You'll stop them from resetting the experiment. I know you will." I hope } \\
\text { she's right. [PRBO] (p. 393) }\end{array}$ \\
\hline 23 & $\begin{array}{l}\text { "[...] you didn't kill Uriah. You didn't set off the bomb that injured him. You } \\
\text { didn't make the plan that led to that explosion." "But I did participate in the } \\
\text { plan." [NSR] (p. 400) }\end{array}$ \\
\hline 24 & $\begin{array}{l}\text { "It happened. It was awful. You aren't perfect. That's all there is. Don't } \\
\text { confuse your grief with guilt." [PRBO] (p. 400) }\end{array}$ \\
\hline 25 & $\begin{array}{l}\text { "No one has ever told me that before," he says softly. "It's what you deserve } \\
\text { to hear," I say firmly, my eyes going cloudy with tears. [PRBO] "That you're } \\
\text { whole, that you're worth loving, that you're the best person I've ever known." } \\
\text { (p. 414) }\end{array}$ \\
\hline 26 & $\begin{array}{l}\text { "Sorry," he says. "I just... you used to be so clumsy, remember? I don't know } \\
\text { how I missed that you weren't like that anymore" [PRBO] (p. 424) }\end{array}$ \\
\hline
\end{tabular}


As with the other novels, the results here are divided into positive selfrepresentation, negative self-representation, positive representation by others and negative representation by others, with the particularity that this novel has two first-person narrators: Tris and Tobias. Presumably because of this division and because of the intense action, there is less discussion of the characters' emotions.

Only on one occasion does Tris describe herself in positive terms in this novel (3): when she tells Tobias that she is reliable, but this situation is more related to their problems as a couple than to her everyday life in the Bureau. On his part, Tobias describes himself as a good runner (9), a physical skill which contrasts with the nature of his insecurities, which is essentially behavioural. More than a positive description, the last example (11) is a negation of Tris' judgement on his behaviour. It is significant to notice how the percentage of positive self-esteem examples are remarkably low in comparison with negative esteem ones as happened with the other novels in the trilogy.

Regarding negative self-representation, most of them (8 out of 11) are about Tobias, which confirms the idea that the novel focuses more on Tobias than on Tris, at least at an emotional level. Tris' negative statements are not strong either. Example 2 simply states that she has lied successfully on various occasions, which is a negative trait, but she does not dwell on her guilt over doing so. In contrast, she perceives her behaviour as negative when she addresses her brother, Caleb. She wants to relate to him in a more positive way and she resents the fact that she cannot forgive him for betraying her (12). Finally, she internally discusses the fact that she used the leader of the Bureau as a human shield and thus is not a hero as most people think (13).

On the other hand, Tobias' insecurities are much more complex. His main insecurity stems from his new status as Genetically Damaged, that is, a nonDivergent individual. Because Tris is Divergent, he may feel inferior and blames his recurrent feeling of inadequacy on that genetic condition. This idea is reflected clearly in examples 7, 10, 17 and 23. In particular, examples 17 and 23 show how his guilt over participating in a terrorist attack that cost his friend's life mingles with the idea that he is damaged, thus reinforcing it. In fact, the responsibility for people's deaths, which was highly present in Tris' esteem results in the previous novel, is highlighted in example 15.

Finally, Tobias' insecurities and negative self-representation are the result of his upbringing. His father was abusive, and his mother faked her death to escape her husband, abandoning him. In examples 4 and 19, Tobias reflects 
on the idea that his behaviour is similar to his parents' behaviour, but only the negative aspects. He hates the fact that he craves control over people, which is a trait his father has, and he is "desperate and afraid" like his mother. In more general terms, having to face his father makes him feel useless and tired (5). In this sense, the structure of the society and its rules were inefficient in identifying the suffering of a child that was physically punished by his father, and that such lack of control affected his development in a negative way, leading to self-esteem issues.

As to how people see the protagonists, nine examples show positive portrayals, and three examples indicate negative ideas. As to the subject of the positive examples, five are about Tris $(6,18,21,22$ and 26) and the others about Tobias $(8,14,24$, and 25$)$.

Tris is respected by the people at the Bureau (6), who have seen her actions in the city. She is praised for her leadership skills in crises (18) and trusted to carry out the mission to save the city (22). Furthermore, Tobias considers Tris to be brave, which, as we have seen, is the most important quality for the Dauntless. Finally, her brother points out that she is no longer the clumsy Abnegation girl (26). She accepts all these remarks willingly except for the one about her heroic feats, mainly because those voicing them -people at the Bureau-were watching through surveillance as people in Chicago died and did not help them.

On the other hand, Tobias receives the support of Tris $(8,25)$ on the matter of his alleged genetic damage. Although in the first case he refuses to accept it, he finally acknowledges the truth. Similarly, Cara comforts him (24) when he feels guilty for Uriah's death (15). Finally, his participation in the GD's attack to the Bureau is praised by Ragi, one of the members of the insurgent group against the Pure-and-Damaged-genes system, but, in this case, Tobias is not convinced that the praise is positive because he feels guilty.

In the last group of examples, we see that the only negative attitude towards Tris is Evelyn's accusation of betrayal (1). She is the leader of the factionless, who fought to overthrow the Erudite leader, Jeanine Mathews. Tris wanted to air information about the purpose of the city, and thus had to protect Jeanine against her superiors' orders. However, this accusation is soon dismissed and has no consequences on Tris' esteem or on people's perception of her. Conversely, Tobias feels the hatred of the community (20) and the discrimination of the Bureau, who defines him as a lesser human being (16). In this case, due to Tobias' already conflicted situation, these situations have a significant negative effect on his esteem. 


\section{Discussion}

Tris starts as an insecure and apparently weak girl and becomes a strong leader. She is demanding, strives for the best and her objective is to achieve a respected position in a profession of her liking. However, the evolution of her selfesteem is not constant. There are several factors that may influence self-esteem, including families and friends, among others. Furthermore, the representation of low self-esteem is notably interesting to understand the prejudices that people in the novels might face.

The role of families in the novels analysed shows that Tris does not rely on her family because they are mostly absent from her life. In this context, she lacks her parents' support, which may explain in part the low self-esteem according to the results. This issue is particularly interesting since she strives to honour the memory of her late parents, but her initial low self-esteem could paradoxically be explained by her parents' parenting style. Parent-child closeness is a determinant of self-esteem. For instance, Harris et al. (2015) found that US and German children's self-esteem presents a positive correlation with their parents' closeness; the researchers asked children questions such as "How often does your mom or dad make you feel tense while you are around her or him?" "How often does your mom or dad show concern for your feelings and problems?" (p. 11). Only by looking at these two items, we may conclude that the parenting style in Tris' upbringing suggests a lack of closeness despite the apparent care and sensibility to other family members' problems. In particular, Tris reports being stressed by not being capable of behaving as her family expects (Divergent: 43). Furthermore, the fact that they are Abnegation and live a life of selflessness impedes Tris and her brother to communicate with their parents or with one another to transmit their anxiety and problems (Insurgent: 213).

The second significant factor influencing the levels of stress and psychological wellbeing related to performance is peer support. Research shows that students who have the support of their classmates present lower levels of academic stress (Torsheim and Bold 2001: 708). Again, Divergent presents the clearest example. The results of the analysis show that Tris presents herself as a girl with low self-esteem who improves her self-image as the novels progress. However, it is noteworthy to remember a particular example in the results in which Tris acknowledges the importance of Tobias' support: 
I thought of how strong I have become, how secure I feel with the person I now am, and how all along the way he has told me that I am brave, I am respected, I am loved and worth loving. (Allegiant: 372).

Sujoldžić and De Lucia (2007: 128) performed a cross-cultural analysis of adolescents' body image and psychological well-being including self-esteem. Their results suggest that positive body image presents a positive relationship with self-esteem in adolescent girls. In these studies, the results show a higher concern over body image by female participants. This fact also applies to the girls in the novels (except for Katniss, whose self-esteem is not affected by her appearance or others' opinion of it), but not to the male protagonists in general, especially Tobias and Elder. In fact, as we have seen, Tobias' positive statement about himself is referred to his physical skills.

Similar to the idea of academic stress and pressure-related low self-esteem, strong friendships have been found to favour a decrease in adolescents' negative perception regarding body image (Kenny, Sullivan, Callaghan, Molcho and Kelly 2018: 7). In the same vein, research reports positive effects of close friendship on teenagers' psychological wellbeing (Wilkinson 2010: 714; Narr, Allen, Tan and Loeb 2017: 1). Drawing on these ideas, I provide a closer examination of the results of self-esteem for the protagonists considering friendships in the Divergent trilogy.

The results gave a very clear pattern for Divergent, where Tris' esteem is affected by very specific events. In particular, she presents 10 instances in which she describes herself in negative terms. A situation that begins to change once she moves to another faction. Even though she continues to present herself in the same terms (clumsy, too small, etc.), she ends the novel with two positive selfrepresentation examples related to her new identity as Divergent and Dauntless (uncontrollable and brave).

After starting her training with the other transfers in Dauntless, Christina and Tris become friends and we see examples of the dynamics of help and compliments that has been identified as typical of female friendships. Even though Tris still refers to herself in negative terms -"I am not pretty-my eyes are too big and my nose is too long"- she acknowledges Christina's compliment: "but I can see that Christina is right. My face is noticeable" (p. 87). This statement is the protagonist's first -and only- positive comment about her physical appearance in the first novel. As pointed out, close friendships are said to improve self-esteem and prevent depression. In this sense, Tris' humour changes when she sees that 
Christina smiles once they join the other Dauntless: "When we walk in, the Dauntless inside stand. They applaud. They stamp their feet. They shout. The noise surrounds me and fills me. Christina smiles, and a second later, so do I" (p. 65). The closeness of the relationship is patent by the way Christina takes care of Tris when she is injured:

Christina just passes me a muffin and crouches in front of me to tie my shoes. Gratitude surges in my chest."-or defending her from Peter's insults: "I feel calmer when I'm near her. If Peter tries to taunt me, she will defend me. (Divergent: 119)

However, as the novels develop, their relationship weakens (e.g., when Tris suggests the best strategy to win the competition), crucially when Tris kills Will in self-defence. Furthermore, the respective relationships of the girls with Tobias and Will establish parallel supports within the faction that eliminate their dependency and reliance between them. The only result of a positive instance by others is Tris' supposition that Tobias considers her a strong person.

While the second instalment of the trilogy starts with Tris following the positive self-esteem ending, her relationship with Tobias is a source of self-deprecating behaviour based on the idea of not deserving him. The compliments she receives are regarding her bravery, but despite Cara's and Tobias' positive comments, Tris develops a kamikaze behaviour derived from the fact that she killed Will and Christina's absence as a support, which derives in her ultimate sacrifice in the last novel. All in all, the trilogy presents a highly negative protagonist who fails to value herself and her life and depends on other people's approval (friends, boyfriend and parents). Regarding this character's evolution, there is no clear improvement, and her nature is self-destructive, which confirms, to some extent, the idea that she represents a martyr (Jarvis 2015).

Finally, the way Tobias reacts to his discrimination as genetically damaged is representative of the negative effects of a highly competitive culture (Dauntless) on targeted males. Parent (2018: 284) points out the relationship between toxic masculinity and depression. Furthermore, Lomas (2017) stresses the fact that adolescent boys at risk -those feeling most vulnerable- may engage toxic masculinity behaviours; they "compensate by engaging in hypermasculine behaviours" such as aggression (p. 2). Thus, Tobias' reaction to his being classified as a lesser human being by the Bureau is to join a terrorist group. 


\section{Conclusion and further research}

This study presents a first approach to the representation of esteem in young adult dystopian novels through the application of a corpus-driven approach based on annotation. The results are analysed and discussed, offering insights into the factors affecting self-esteem and esteem in the popular Divergent trilogy, by Veronica Roth (2011-2013). In particular, the main factors include family and peer support, the classification systems (factions and genetic classification), and social responsibility. Additional topics discussed include physical appearance, expectations, and agency.

The results suggest the evolution of a protagonist whose self-esteem is affected by an inadequate parenting style and lack of peer support. The protagonist's positive evolution is nonetheless affected by the influence of friends' support and lack thereof, but most importantly by the consequences of the great responsibility that the protagonist has to endure first due to social expectations as part of Abnegation, and then as a rebel in a war-like context. Finally, it is also worth mentioning that while the female protagonist describes herself in negative terms not only as to her physical appearance but also regarding her capabilities, the male protagonist, who is a narrator in the last novel of the trilogy, only doubts his skills.

As to external perspectives or representation by others, we see that while Tris is reassured by her friend Christina, her self-esteem is positively affected, but after the distancing between the two friends, the only reassurance she receives, from her boyfriend, does not influence her self-esteem in a positive way as per the results. Thus, friendship seems an important determinant of self-esteem in these novels.

Future research will compare esteem representation in various YA dystopian novels of the twentieth century in order to identify possible patterns and differences. Furthermore, this methodology could be applied to identify other psychological or sociological aspects of the societies in the novels.

\section{References}

AMES, M. (2013). "Engaging "apolitical” adolescents: Analyzing the popularity and educational potential of dystopian literature post-9/11". The High School Journal 97: (1): 3-20.

AMES, M. (2018). "Responsibility in the composition classroom" in Young Adult Literature in the Composition Classroom: Essays on Practical Application. (Eds. T. Girardi and G. Scheg). Jefferson: McFarland: 21-29. 
BALL, R. (2016). Actors and aliens: Representations of Teenage Protagonists in Bestselling YA Fiction. (Doctoral thesis). Victoria University of Wellington. $<$ https://researcharchive.vuw.ac.nz/xmlui/bitstream/handle/10063/6127/ thesis.pdf? sequence $=1>$.

BASU, B., BROAD, K. R. and HINTZ, C. (Eds.) (2014). Contemporary Dystopian Fiction for Young Adults: Brave New Teenagers. New York: Routledge.

CAMPANELLA, T. (1602) (2009). The City of the Sun. SMK Books.

COLLINS, S. (2008). The Hunger Games. New York: Scholastic.

COLLINS, S. (2009). Catching Fire. New York: Scholastic.

COLLINS, S. (2010). Mockingjay. New York: Scholastic.

DAY, S. K., GREEN-BARTEET, M. A. and MONTZ, A. L. (Eds.) (2014). Female Rebellion in Young Adult Dystopian Fiction. Farnham: Ashgate Publishing.

HARRIS, M. A., GRUENENFELDER-STEIGER, A. E., FERRER, E., DONNELLAN, M. B., ALLEMAND, M., FEND, H., CONGER, R. D. and TRZESNIEWSKI, K. H. (2015). "Do Parents Foster Self-Esteem? Testing the Prospective Impact of Parent Closeness on Adolescent Self-Esteem". Child Development 86 (4): 995-1013. https://doi.org/10.1111/cdev.12356.

HINTZ, C. and OSTRY, E. (Eds.). (2003). Utopian and Dystopian Writing for Children and Young Adults. London: Routledge.

HOOVER, D. L., CULPEPER, J. and O'HALLORAN, K. (2014). Digital Literary Studies: Corpus Approaches to Poetry, Prose, and Drama (Vol. 16). London: Routledge.

JARVIS, C. (2015). "How to be a woman: Models of masochism and sacrifice in young adult fiction" in Popular Culture as Pedagogy: Research in the Field of Adult Education. (Eds. K. Jubas, N. Taber y T. Brown). Rotterdam: Sense Publishers: $134-150$.

JERKOVIĆ, S. V. and ALIHODŽIĆ, D. (2018). “The Hunger Games in BosnianHerzegovinian context: the study of the effects of young adult dystopian literature on high-school students". Društvene i Humanističke Studije 1 (4): 223-238.

KENNY, U., SULLIVAN, L., CALLAGHAN, M., MOLCHO, M. and KELLY, C. (2018). "The relationship between cyberbullying and friendship dynamics on adolescent body dissatisfaction: a cross-sectional study". Journal of health psychology 23 (4): 629-639.

KOUTSOULELOU, S. (2017). "Crisis is written all over me. Greece in Crisis: Combining critical discourse and corpus linguistics perspectives" in Greece in Crisis: Combining critical discourse and corpus linguistics perspectives. (Eds. O. Hatzidaki and D. Goutsos). Philadelphia: John Benjamins: 263-289. 
DYSTOPIAN FICTION IN ENGLISH: A CORPUS-DRIVEN ANALYSIS OF ESTEEM IN VERONICA ROTH'S...

LOMAS, T. (2017). "Can Mindfulness help at-risk adolescent boys?" in Making a Difference with Psychology. (Eds. K. Niven, S. Lewis and C. Kagan). Manchester: Richard Benjamin Trust: 113-120.

LOWRY, L. (1993). "The Giver Quartet Omnibus" in L. Lowry (2014), The Giver Quartet Omnibus. Boston: HMH Books for Young Readers.

MARSHALL, M. (2014). "What Mainstream Centers Cannot Hold: Growing Critical Literacy with Dystopian Fiction" in Teaching towards Democracy with Postmodern and Popular Culture Texts. (Eds. P. Paugh, T. Kress and R. Lake). Rotterdam: Brill Sense: 135-150.

MORE, T. 2010 (1516). "Libellus vere aureus, nec minus salutaris quam festivus, de optimo reipublicae statu, deque nova insula Vtopiae" in Utopia (Ed. L. Winkler). Scotts Valley, CA.: CreateSpace Independent Publishing Platform.

NARR, R. K., ALLEN, J. P., TAN, J. S. and LOEB, E. L. (2017). “Close friendship strength and broader peer group desirability as differential predictors of adult mental health". Child development 90 (1): 298-313. https://doi.org/10.1111/ cdev.12905.

PARENT, M. C., GOBBLE, T. D. and ROCHLEN, A. (2018). Social media behavior, toxic masculinity, and depression. Psychology of Men \& Masculinity. Advance online publication. http://doi.org/10.1037/men0000156.

PATAKI, J. (2017). "To read and learn: The necessity for a new definition of dystopia and bridging the gap between the old and contemporary dystopias" [review of D. Alihodžić and S. Veseljević Jerković, The Boundaries of Dystopian Literature. The Genre in Context]. Anafora-časopis za znanost o književnosti 4 (2): 426-430.

PIOTROWSKI, A. and RYBAKOVA, K. (2015). "Reading adolescents in dystopian YAL through the lens of feminism". GALA Journal: A Journal of the Gender in Literacy and Life Assembly 21: 23-30.

SAUNDERS, J. M. (2014). "What the Hunger Games can teach us about disciplinary literacy." English Journal 103 (3): 41-47.

SIMMONS, A. M. (2014). "Class on fire: Using the Hunger Games trilogy to encourage social action" in Teaching towards Democracy with Postmodern and Popular Culture Texts (Eds. P. Paugh, T. Kress and R. Lake). Rotterdam: Brill Sense: 77-95.

SOARES, M. A. (2018). "Here's looking at you kids: The urgency of dystopian texts in the secondary classroom" in Worlds Gone Awry: Essays on Dystopian Fiction (Eds. J. J. Han, C. C. Triplett and A. G. Anthony). Jefferson: McFarland: 210-224. 
SUJOLDŽIĆ, A. and DE LUCIA, A. (2007). "A cross-cultural study of adolescents-BMI, body image and psychological well-being". Collegium Antropologicum 31 (1): 123-130.

SWIFT, J. (1723) (2009). "Travels into several Remote Nations of the World. In Four Parts" in Gulliver's Travels. Reading: Oneworld Classics.

TORSHEIM, T. and WOLD, B. (2001). "School-related stress, support, and subjective health complaints among early adolescents: A multilevel approach". Journal of adolescence 24 (6): 701-713.

TRITES, R. S. (2000). Disturbing the Universe Power and Repression in Adolescent Literature. Iowa City, IA: University of Iowa Press.

VAN MELCKEBEKE, S. (2018). Young Adult Dystopian Literature. Didactic Benefits of its use in the English Subject Classroom in Norway (Master's thesis). Inland Norway University of Applied Sciences.

WESTERFELD, S. (2005). Uglies. New York: Simon Pulse.

WESTERFELD, S. (2005). Pretties. New York: Simon Pulse.

WESTERFELD, S. (2006). Specials. New York: Simon Pulse.

WILKINSON, R. B. (2010). "Best friend attachment versus peer attachment in the prediction of adolescent psychological adjustment". Journal of Adolescence 33 (5): 709-717. 